\title{
特別講演「我が国の高等教育政策の動向と 工学教育の充実」
}

The Trend of Higher Education Policy in Japan and Encouragement for Technical Education

\author{
澤 川 和 宏※1 \\ Kazuhiro SAWAKAWA
}

1.はじめに

文部科学省高等教育局専門教育課長の澤川と申しま す。本日はよろしく㹉いします。「我が国の高等教 育政策の動向と工学教育の充実」について，話をさせ ていただきます。

\section{2. 我が国の高等教育政策の動向}

\section{1 高等教育政策をめぐるこれまでの大きな流れ}

まず我が国の高等教育政策の動向について, 教育基 本法の話を簡単にさせていただきます。平成18年12月 に教育基本法が改正されました。昭和 22 年に制定され て以来改正されてこなかったので，約60年ぶり初めて の改正となります。昭和 22 年当時の教育界の最大の テーマは何かというと, 新制中学の設置と義務化でし た. 改正前の教育基本法を見ると，「9 年の普通教育 を受けさせる」と規定し，「男女の共学は認められな ければならない」とするなど，戦後間もないころの時 代背景を大きく反映した条文になっておりました。高 等教育の普及など社会情勢の変化を踏まえて，教育基 本法の中に，高等教育の記述がないとか，家庭と地域 との連携の規定がないということで，平成18年の見直 しとなりました.

大学については, 第 7 条第 1 項に抒いて「高い教養 と専門的能力を培う」と教育に関する文言と，「媣く 真理を探究して新たな知見を創造する」と研究に関す る文言があります。さらに「社会の発展に寄与する」 との文言を含めて，第 7 条が構成されています．第 2 項ですが, 大学について,「自主性, 自律性の尊重」 が規定されています。すなわち，大学は教育と研究を 車の両輪とするというこれまでの考えや，大学の自治 といった基本的な考えを, 教育基本法の新しい第 7 条 において確認するとともに，社会への貢献という新た な役割が明確にされたということです。

私は，直接，教育基本法の改正作業に携わったわけ ではございませんが，担当職員と議論する機会がいろ

平成 21 年 11 月 6 日受付

※1文部科学省高等教育局専門教育課
いろありました。細かいことは学校教育法などに記述 すればよく, 教育基本法に教育制度すべてを盛り込む 必要はないので, 教育基本法に規定すべき教育制度を 形づくる基本は何かということについてです．国際的 通用性を踏まえると, 義務教育と大学になるというの が結論でした。すべての先進国，近代的な教育制度を 採っている国においては，義務教育と大学は，必須の 二大要素ということです.

教育基本法の改正を受けて，平成19年 6 月に，いわ ゆる教育 3 法, 学校教育法などが改正されました。学 校教育法第 83 条が大学に関する規定で, 教育基本法の 考え方を受けています．また，第 2 項が追加され，「社 会貢献」という大学の役割があらためて明確になりま した。

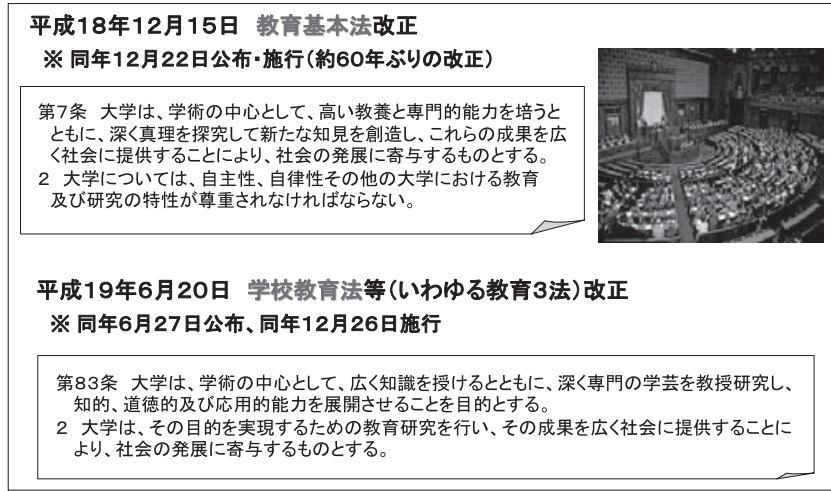

図 1 高等教育をめぐるこれまでの大きな流れ(1)

次に, 教育振興基本計画について説明します。教育 については, 長らく基本計画というものが存在せず, 改正された教育基本法に基づいて初めて, 昨年 7 月に 「教育振興基本計画」が策定されました。「今後 5 年間 に総合的かつ計画的に取り組むべき施策」が中心とな るものです，幼児教育, 初等中等教育, 高等教育, 社 会教育など，全体で約七十項目の施策が盛り込まれて います。

「大学等の教育力の強化と質保証」としては, 厳格 な成績評価システム等について施策が揭げられていま す.「卓越した教育研究拠点の形成」では, 数值目標 を掲げながら進めており,「大学等の国際化の推進」 では，留学生30万人計画について触れています。その 
他「キャリア教育・職業教育の推進」など高等教育に 関する施策が多数盛り込まれているところです.

また，高等教育については，「この 5 年間を高等教 育の転換と革新に向けた始動期間として位置づけ，中 長期的な高等教育の在り方について検討し, 結論を得 ることが求められる.」とされており，平成 20 年度か ら 24 年度までの 5 年間を貫く基本的な姿勢を，この文 言で明らかにしています。この「転換と革新」という キーワードが何かということが，私の今日の話の前半 のテーマです.

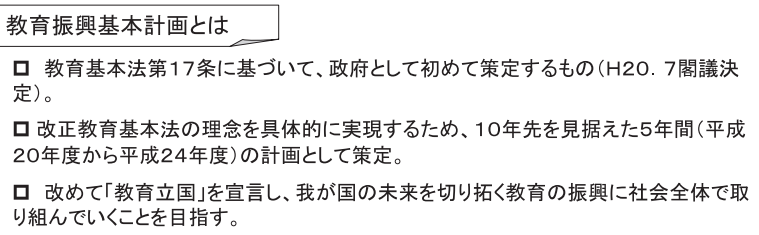

\section{今後5年間に総合的かつ計画的に取り組むべき施策}

<高等教育関係抜粋>

○大学等の教育力の強化と質保証

○卓越した教育研究拠点の形成と大学等の国際化の推進

○キャリア教育·職業教育の推進と生涯を通じた学び直しの機会の提供の推進

この5年間を高等教育の転換と革新に向けた始動期間と位置づけ、中長期的な 高等教育の在り方について検討し、結論を得ることが求められる。

図 2 高等教育をめぐるこれまでの大きな流れ(2)

\section{2 中央教育審議会における議論}

私なりの見解ですが, 今後の方向性としての「転換 と革新」の答えは，すべて平成17年の中央教育審議会 「我が国の高等教育の将来像」に書いてあると考えて います.

平成17年の将来像答申の基本的な認識としては, 我 が国の高等教育政策は転換せざるをえない状況にある ということです，従来の高等教育政策は，進学率な どに対応して高等教育計画を策定し，これに基づき， 文部科学省の設置認可により事前規制をしていまし た。しかしながら，18歳人口が減少し，収容率がほぼ 100\%になった状況では，この従来の政策手法は使命 を終えたと将来像答申の中で明確に言っているわけで す．今後の政策の在り方としては，国が高等教育の将 来像を示した上で，それぞれの高等教育機関の判断の 結果が，国全体として望ましい姿になるように，政策 的に誘導していくということです.

この基本的な考え方に沿って，具体的な提言が行わ れております.まず,「1. 高等教育の量的変化」ですが, 大学等の収容率が $100 \%$ になる状況では, 量的な面で はなく,質的な面でのユニバーサルアクセスの実現が, これからの課題ということです。

また, 「2，高等教育の多様な機能と個性，特色の 明確化」では，「(1)世界的研究·教育拠点」など，(1) 〜 (7)の方向性を示しつつ, ユニバーサルアクセスに 応えるためには，それぞれの高等教育機関が自ら機能 別分化を果たしていかなければいけないという方向性
を示しています.

その上で「3. 高等教育の質の保証」ですが, 大学 の量的拡大 - 機能別分化の中で, 学習者の保護, 国際 的通用性を確保するためには, 高等教育の質の保証が 重要になってきます. 高等教育の質の保証の 3 つの要 素として, 事前の評価としての「設置認可」, 事後評 価としての「認証機関による第三者評価」と「自己点検・ 評価」がこれから重要になってくると述べています.

この将来像答申を読んでみますと「大学とは何か？」 という文言がたびたび出てきます，答申の当時，規制 改革等の流れがあり, 高等教育機関が大きく変容しま した，そういった中で，そもそも大学が因って立つも のは何かという問題意識が希薄化しているのではない かという危機感がありました。この「大学とは何か？」 という危機感に対応するのが，「3．高等教育の質の 保証」だと思っています。

次に「4．高等教育機関のあり方」です．これまで 学部・学科など, 組織に焦点を当てて私達は大学をと らえてきましたが, これからは，学位を与える課程中 心にとらえ直すべきではないかということです.

さらに 5 番目に，高等教育財政の充実を提言してい ます.

以上のように，これからの 21 世紀の高等教育のあり 方を提案したのが将来像答申だと考えています。

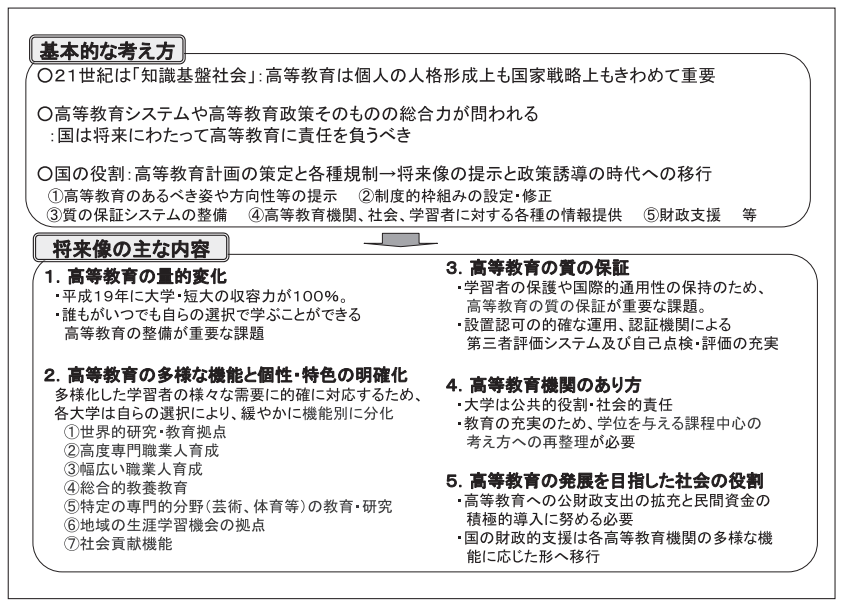

図 3 高等教育をめぐるこれまでの大きな流れ(3) 中央教育審議会答申「我が国の高等教育の将来像」 (H17. 1. 28)

先ほど教育振興基本計画のところで申し上げた，今 後 5 年間は転換と革新に向けた始動期間ということで すが, この「転換と革新」を具現化するのが, 平成 20 年 9 月11日の中央教育審議会への諮問です. 諮問内容 は, 「1．社会や学生からの多様なニーズに対応する 大学制度と教育の在り方」, 「2. グローバル化の進展 の中での大学教育の在り方」,「3.人口減少期におけ る我が国の大学の全体像」です。

この諮問の趣旨については, 新しい制度・しくみの 導入を目指すものではなく, 既存の制度・しくみを論 理的に整理して, 現時点での意義・妥当性を点検する 
ものであるとご理解頂きたいと思います.

先ほどの平成17年の将来像答申が出た時，もうすで に高等教育の体組みは, 相当大きく変わっていました. 国立大学の法人化や，弾力化・準則化など設置認可の 在り方の見直し，認証評価機関による第三者評価の導 入など，高等教育の在り方は，平成17年答申の前に大 きく変わっています.

その点について, 将来像答申の冒頭で基本的な認識 が示されており，これからの高等教育政策は，もうシ ステム改革の時代ではなく各高等教育機関が活性化の 成果を具体的に競い合う段階へと移っているとしてい ます。

それと、この中教審への諮問を対比していただけれ ば, 諮問の趣旨がよくおわかりいただけると思います。 つまり，先ほど教育振興基本計画にあった「転換と革 新」に向けて，平成17年の将来像答申に沿って，既存 のしくみや制度を点検していくための諮問であるとご 理解いただければと思っています。

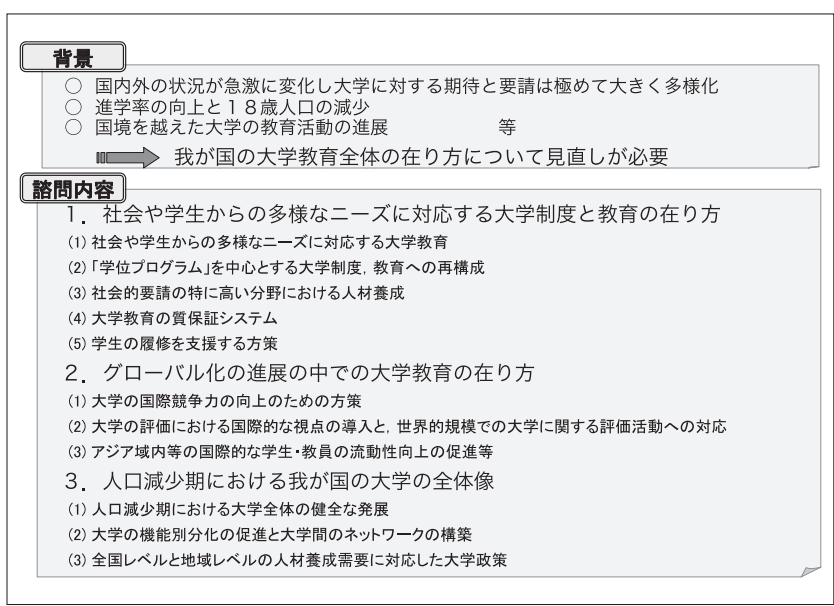

図4 高等教育をめぐるこれまでの大きな流れ(4)

中央教育審議会諮問「中長期的な大学教育の在り方 について」(H20.9.11)

この諮問後，平成 21 年 6 月 15 日に，第一次報告がな されています，第一次報告の基本的なキーワードは， 「大学の構造転換の必要性」です。その中で特に，「質 保証システムの構築」と「量的規模の在り方の検討」が, 第一次報告に扔ける主な提言です。

私なりの理解としては，2つある大きな提言の中で, 質保証に，かなり軸足を置いたものだと思っております.

特に，この「質保証」につきましては，先ほど将来 像答申の中で申し上げた，「そもそも大学とは何か？」 という根源的な問いに対し，しっかりとした答えを出 さなければいけないという危機意識と, ヨーロッパに おけるボローニャ・プロセスなど，国際的な動向も踏 まえて, 大学の質保証システムの構築が契緊の課題で あるという認識に立っています。

「(1) 公的な質保証システムの検討」では, 事前評 価としての「設置基準」と「設置認可審査」と, 事後 の評価としての「認証評価」について，もう少し前に

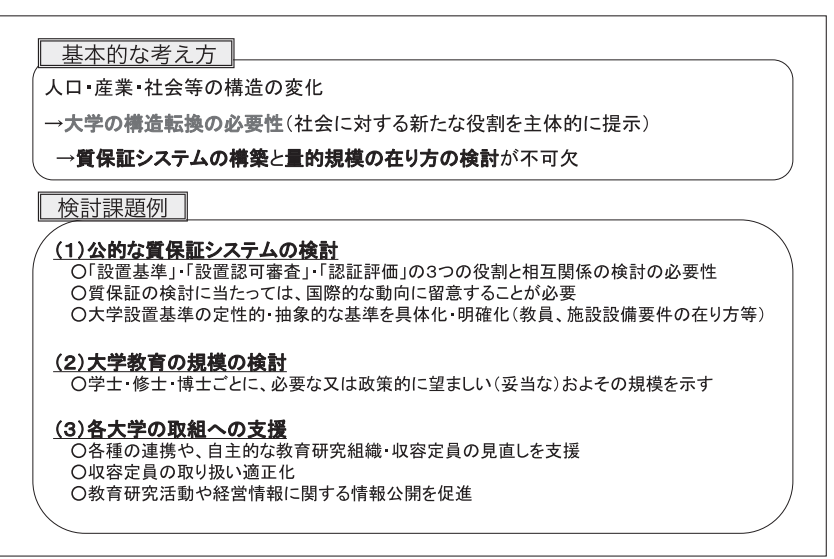

図 5 高等教育をめぐるこれまでの大きな流れ(5) 中央教育審議会大学分科会「中長期的な大学教育の 在り方に関する第一次報告 - 大学教育の構造転換に 向けてー」(H21.6.15)

進めましょうと言っています。

大学設置基準については, 定性的・抽象的でわかり づらい, という指摘がありますので, 具体化・明確化 の検討作業を進めようというわけです.

$\lceil(2)$ 大学教育の規模の検討」については, 第一次 報告では必ずしも十分触れていないと思っています. 学士・修士・博士ごとに必要な規模を示すということが, 触れられているのみです．量的規模の検討については， まずは大学院から始める方向で議論が進んでいます.

平成17年の将来像答申は, 高等教育の在り方にかか わる非常に広範な提言も含んでいますので，それを一 歩一歩, 論理的に分析しながら, できることからやっ ていこうということが, 今の高等教育政策の在り方だ ということをご理解いただければと思います.

\section{3 科学技術基本計画について}

「科学技術基本計画」については, 現在, 第 3 期目 で, 平成18～22年度までの 5 年間の基本計画を実施 しているところです。平成 7 年に科学技術基本法が制 定され，それに基づき，平成 8 年度に第 1 期の基本計 画が策定され, 科学技術関係の投資総額を 17 兆円とし ていました。 そして第 2 期基本計画では「重点分野の

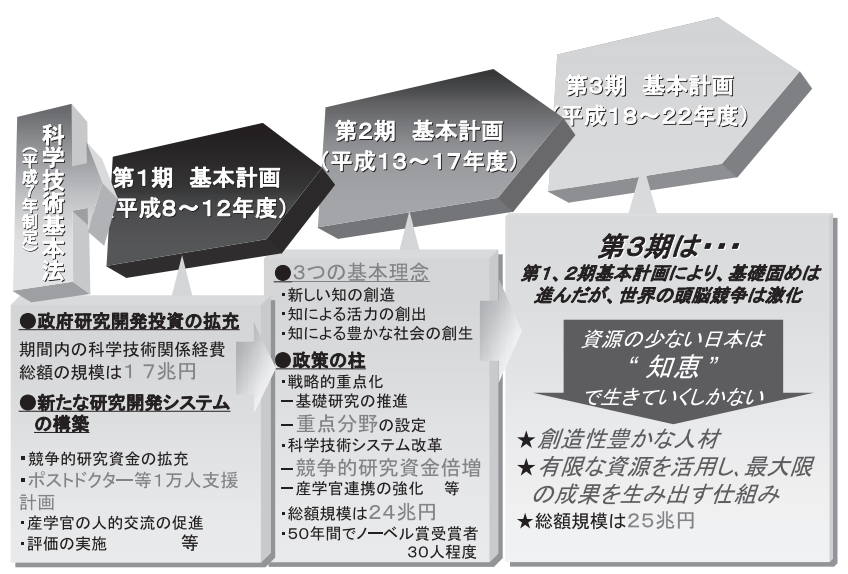

図 6 高等教育をめぐるこれまでの大きな流れ (6) 科学技術基本計画について 
設定」や「競争的研究資金倍増」などが政策の柱であ りました．現行の第 3 期基本計画については，基本的 な考え方を，「ものから人へ」としており，資源の少 ない日本において, 人材育成に軸足を置いていこうと いうものです.

現在，第 4 期科学技術基本計画策定に向けて，いろ いろ検討が進められているところです。第 3 期の人材 育成重視という考え方をさらに進め,「基礎科学力の 強化」を大きなテーマとして検討しています.

平成21年4月28日、科学技術·学術審議会基本計画特別委員会が設置（第1 回委員会: 平成 21 年 6 月 2 日開催)され、第4期基本計画策定に向けて検討中。

\section{主な検討視点}

1. 基本認識: 我が国の中長期的に目指すべき国の姿と科学技術のあり方、政府研究開発投資目標

2. 科学技術の戦略的重点化

基礎科学力強化の観点も含めた基礎研究のあり方、政策課題対応型研究開発

3. 科学技術システム改革

科学技術人材の育成確保、イノベーション・システム改革、

世界的研究拠点形成、研究環境、基盤整備

4. 科学技術の国際活動の戦略的推進: 科学技術外交の積極的な展開、国際科学協力等

5. 科学技術と社会との関係深化: 国民の理解增進活動等

6. 科学技術推進体制の在り方: 総合科学技術会議や各省庁との連携·調整のあり方等

$\rightarrow$ 平成21年12月を目途に、基本計画に盛り込むべき重要政策についてとりまとめ予定

図 7 高等教育をめぐるこれまでの大きな流れ(7) 第 4 期科学技術振興基本計画策定に向けて

\section{3. 工学教育をめぐる現状}

工学離れ, 理工系離れといわれますが,「工学関連 学部」の入学志願者については, 平成 4 年の約 89 万人 をピークに, 平成 19 年は 52 万人 4 割以上の減となっ ています。

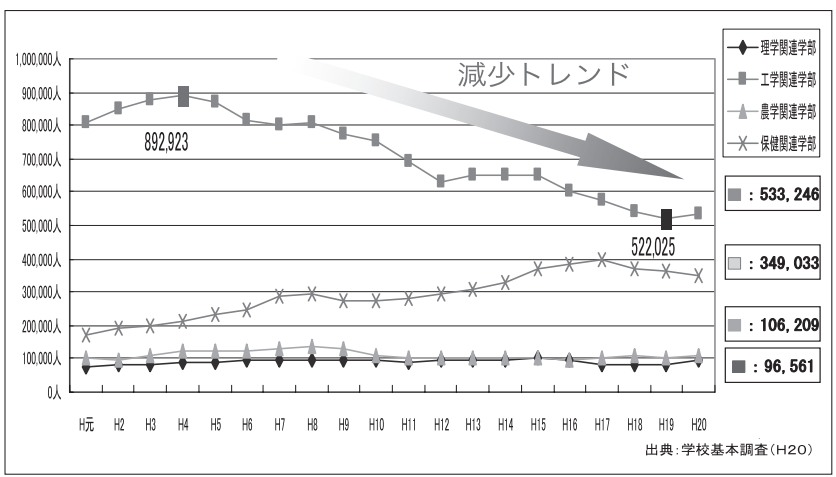

図 8 関連学部別入学志願者数の現状比較

これに関連して，初等中等教育における理科教育の 現状について紹介します. TIMSS（国際数学・理科 教育動向調查）という理数教育に関する国際的な調査 によりますと，「理科に対する児童生徒の意識」につ いて,「理科の勉強が大切だ」と思う生徒,「理科の勉 強が好きだ」と思う生徒の割合は，小学校 5 年生と中 学校 2 年生を比較すると, いずれも大きく減少してい ます。

また，国際比較で見ると，残念ながら我が国の子ど もたちで，理科の授業を楽しいと思う割合は，アメリ
カ, シンガポール, 国際平均に比べて少ない, という 現状にあります。

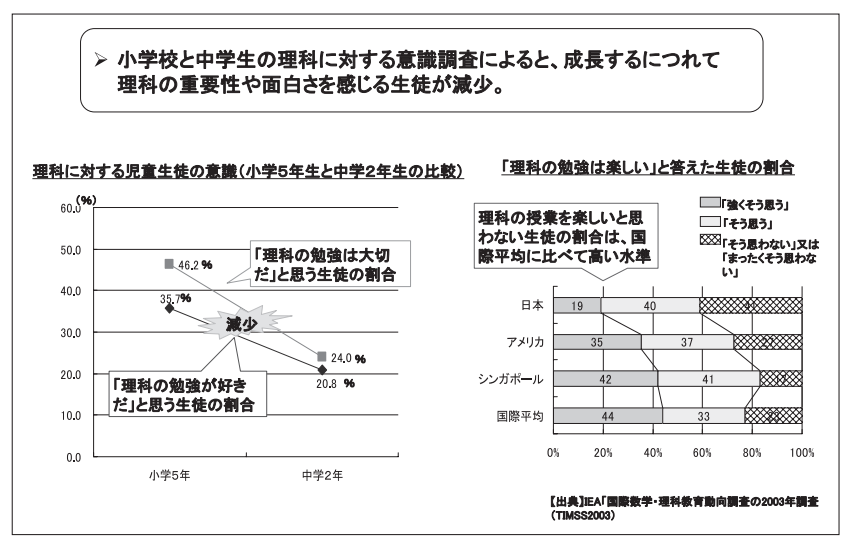

図 9 小中校生の理科への関心

どうして子どもたちが「理科の勉強は楽しくない, 理科が好きではない」と思うようになったのかについ ては，その 1 つの有力なデータとして，J S T (独立 行政法人科学技術振興機構）が実施した小学校教員の 理科に対するアンケートがあります. 理科を教える教 員の約 9 割が理科が好きだと感じていますが, 指導技 術についての自己評価は, 理科を教える教員の約 5 割 が「苦手」か「やや苦手」と, 理科に対する苦手意識 を持っていることがうかがえます。

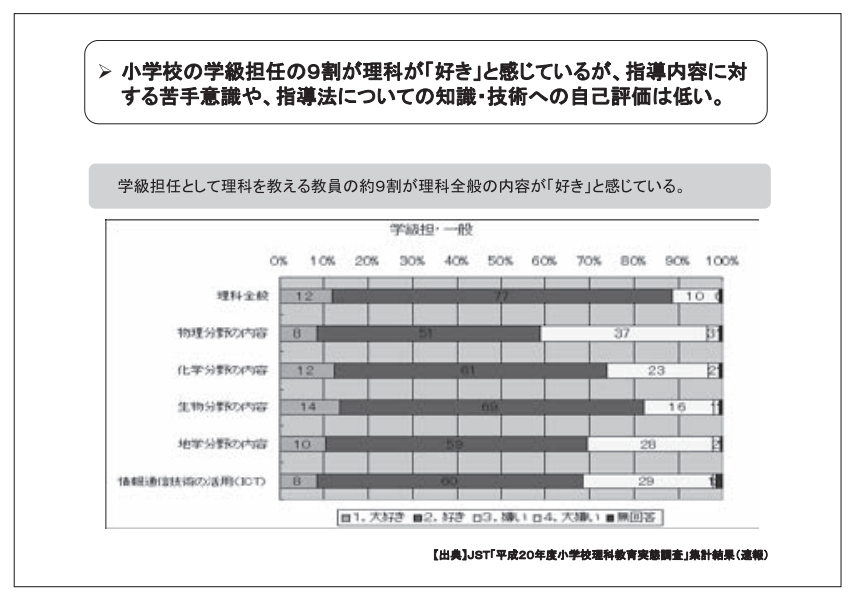

図10 小学校教員の理科に対する意識(1)

また,「教職経験 5 年未満」である若手教員の実に 9 割が理科の指導方法について苦手意識を持っている という現状にあります。

先ほどのTIMSSの調査とJSTの調査を総合して考察 してみますと, 基本的には, 子どもは理科が好きであ ると今の時代に扔いても言えると思います。しかし, 学校教育の問題, 特に教員の指導力など様々な課題に より,成長していくにつれて, 理科に対する興味を失っ ていく,ということが言えるのではないかと思います. この理数教育については，国としても充実していく 方針であり, 昨年, 小中学校の学習指導要領が改訂さ れ, 平成23年度から小学校全面実施になっています. $\lceil 2$. 理数教育の充実」については, 国際的通用性や 小中高の円滑な接続を図るという観点から, 理科等の 


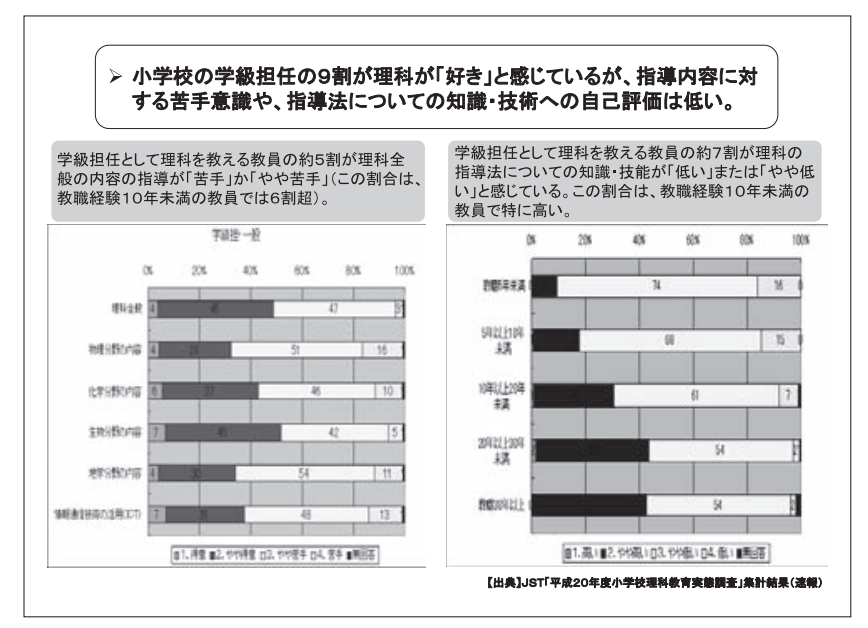

図11 小学校教員の理科に対する意識(2)

授業時数を増やし，充実を図ることになっています.

「授業時数」については, 理科と算数 (数学) で, それぞれ約 2 割から 3 割の増を図っています，指導内 容についても，様々な充実を図っています。

しかしながら，大切なのは，実際にそれを子どもた ちに教える教員の質ではないでしょうか.

理科について専門的な知識を持った皆様方が，学校 教育を支援していただくとともに，教育者を志す理系 の方が扔られたら，ぜひとも教員の門をたたいていた だきたいと思います。

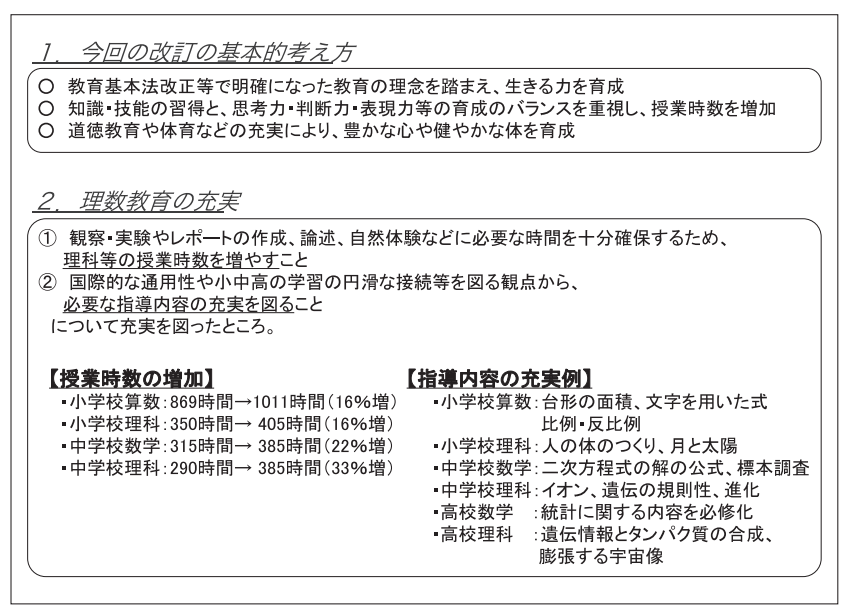

図12 学習指導要領の改訂について

また，工学離れをめぐるもう 1 つのデータとして， 高校生・受験生に対するアンケートがあります，河合 塾が実施した調查では高校生・受験生のうち 8 割が, 工学部に対する具体的なイメージがないという結果で す.

高校の教員に,「生徒に工学系に目を向けさせるに は，どのような情報の紹介が必要だと思いますか」と 聞いたところ,「研究室の研究内容・研究成果」や「卒 業後の仕事の内容」となっております.

本日損まりの工学系の皆様方に扔かれましては, 是非情報発信を直接, 高校生・中学生にしていただけ ればと思います。

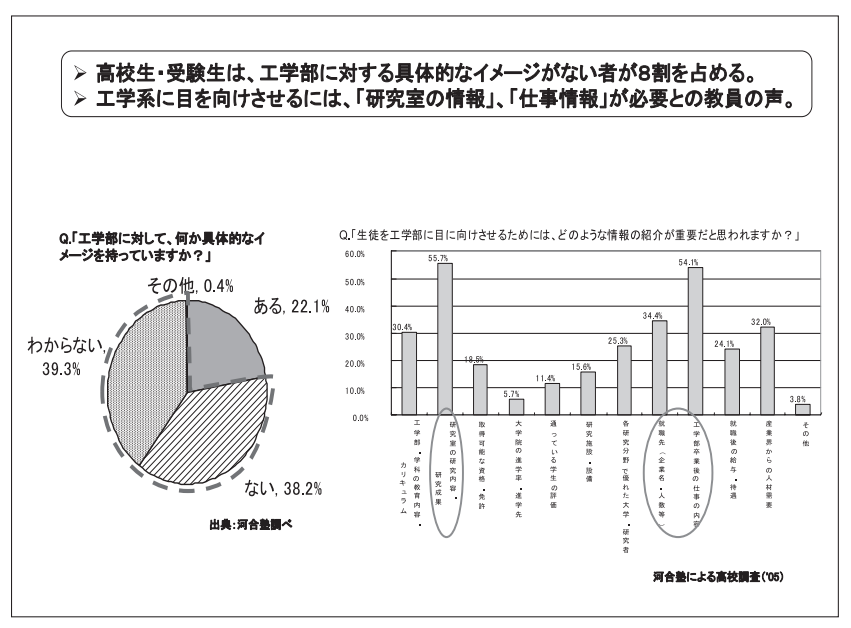

図13 進学情報を取り巻く環境

\section{4. 工学教育の充実に向けて}

次に, 文部科学省専門教育課の施策に関し, 高等専 門学校教育の充実, 先導的ITスペシャリスト育成推 進プログラム, 産学人材育成パートナーシップ, 大学 に打ける技術者教育のあり方に関する協力者会議の 4 点について, 説明します。

4. 1 高等専門学校教育の充実について

まず高等専門学校教育の充実について，平成20年12 月に, 中教審で答申が出ています，高等専門学校につ いては, 高い就職率・求人倍率など社会から高い評価 を得ているという基本認識が示されています.

こうした高等専門学校の優れた教育機能をさらに充 実・発展させていくため, 専攻科も活用しながら, 産 業界と連携してイノベーション創出に貢献する人材を 育成するなどの提言がされています.

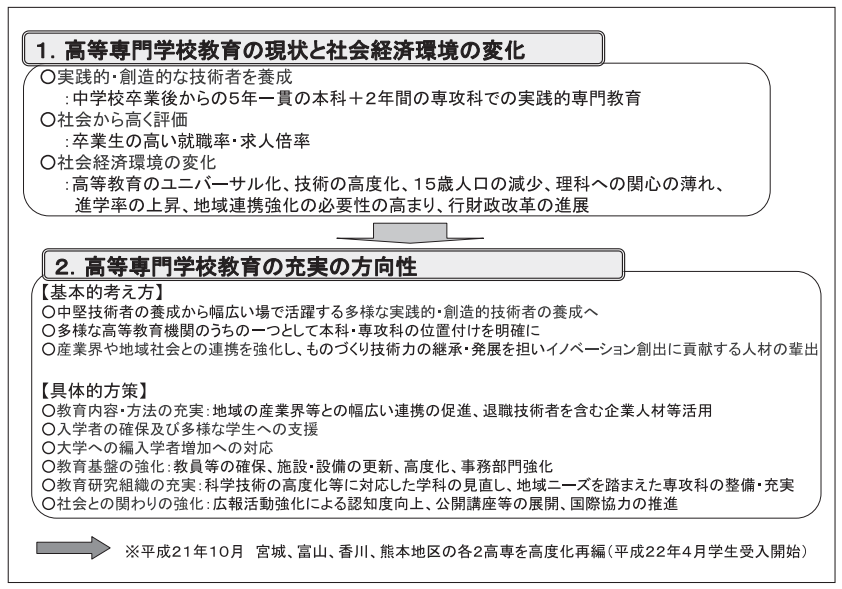

図14 中央教育審議会答申「高等専門学校教育の充実につ いて」(20.12.24)

\section{2 先導的 ITスペシャリスト育成推進プログラム} 次に,「先導的ITスペシャリスト育成推進プログラ ム」は平成18年度から始まった事業ですが, 我が国には, 即戦力となる高度な IT技術を持った人材がいない, こ のままでは我が国の国際競争力を維持することはでき ないという経済界の強い危機意識が背景にあります.

大学間・産学の壁を越えて, 世界最高水準の ITスペ 
シャリストを育成する教育拠点を形成するという方針 のもと，全国で 8 拠点を作り，企業の第一線で活躍す る人材を教員として派遣したり，カリキュラムを共同 で開発するなど産学が連携した取組を推進しています。

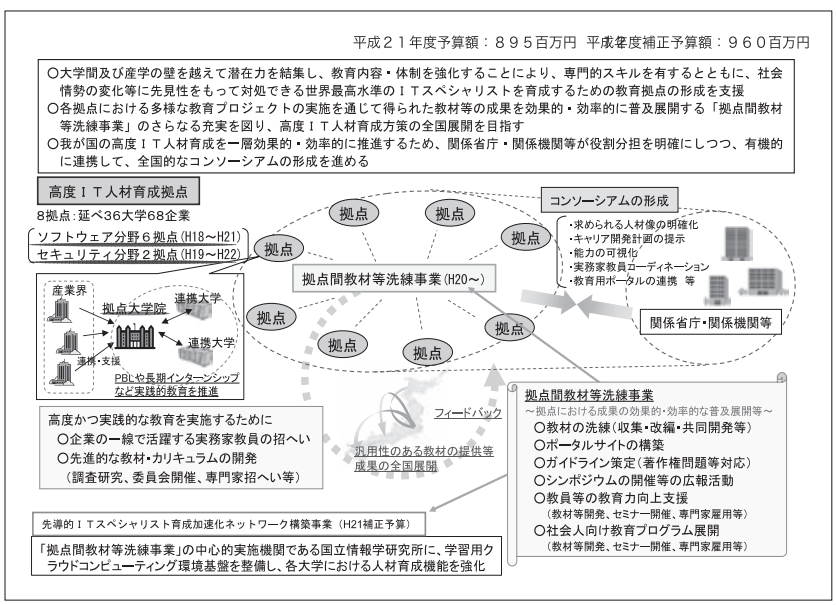

図15 先導的 IT スペシャリスト育成推進プログラム

名古屋大学も拠点の 1 つであり, 近隣の南山大学, 愛知県立大学, 静岡大学や周辺の企業と連携しながら 事業を展開しています．オン・ザ・ジョブ・ラーニング ということで, 企業と連携しながら, 大学の中では体験 できない実際のものづくりにおける開発プロセスを学生 に学ばせ, 現場で役立つ高度な人材を育成していこう という事業です．私から見ても非常に高度な取組を行っ ており，企業からの評価も高いと聞いて扔ります。この 事業は，今年度で大半が終了してしまいますが，来年 度に向けて, 充実させていきたいと思っております。

\section{3 産学人材育成パートナーシップ}

次に, 産学人材育成パートナーシップについてです. 産業界と大学の双方向での対話の場を設定するため に，平成19年から始めた事業です，企業側からは，卒 業生が十分な能力を有していない，技術が低いという 指摘があり, また大学からは, 育てた人材が有効に活 用されていないという意見が言われ，双方の認識の隔 たりが大きい現状にありますが，お互いがそれぞれ歩 み寄って, 意見を真摰に戦わせながら, 協力して人材 育成に取り組んでいこうというものです，全体会議の 下の $9 つ の$ 分科会で，それぞれの分野において，検討 が行われております。

\section{4 大学における実践的な技術者教育のあり方に 関する協力者会議}

最後に,「大学における実践的な技術者教育のあり 方に関する協力者会議」についてです．国際的通用性 を確保し，産業界からのニーズに対応しうる，質の高 い技術者養成に向けて, 今一度, 大学に扔ける技術者 教育のあり方を見直していこうというものです，技術 者として身につけるべき基本的な資質や，効果的な力 リキュラムのあり方について, 今後検討を進めていく 予定です。

\section{5.おわりに}

最後になりますが, 「今後の工学教育への期待」に ついて申し上げます. 今年前半, 我が国において最も 重要な政策課題は何であったかといいますと, 経済財 政運営と構造改革に関する基本方針 2009 においてク ローズアップされた「安心」です，経済危機・金融危 機に伴う世界経済の危機の中, まずは生活の安心をつ くるのが, 政府の役目であるということです.

教育の世界では, 授業料の減免や奨学金など, 教育 費負担の軽減が，大きくクローズアップされました。 しかし、はたして安心だけで良いのでしょうか. 危機 の中においては確かに, 安心という観点が重要ですが, 本質的な意味での安心を確立するには, やはり活力や 発展がなければなりません.

経済財政運営と構造改革に関する基本方針 2009 に おいては, イノベーションにより，産業構造を大きく 転換して, 我が国が持続的成長を成し遂げ, 究極な意 味での安心社会の実現を目指しております。我が国の 活力や発展を支える人材育成という観点では, 我が国 が強みを持つ分野である, 工学, ものづくりが重要と なります. 工学教育に寄せる期待は非常に大きいもの があります．理工系教育に関する魅力の発信の必要性 も，あらためて強調したいと思います。

やはり, 子どもは, 本来的には, 知的好奇心を刺激 されるものづくりや科学が大好きです.

子どもたちが, 知的好奇心を維持し, それを持って 社会に出て, 貢献できるのであれば, これほどすばら しいことはないと思います。これからの工学教育に寄 せる期待は，非常に大きなものがあります．皆様方の これからのご活躍を期待しております. 今後とも, 皆 様方と二人三脚で工学教育の充実に努めてまいりたい と考えています。ご静聴ありがとうございました.

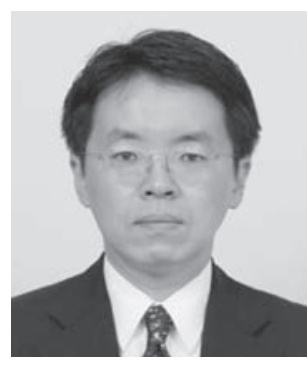

\section{著 者 紹 介}

澤川 和宏

1990年 4 月 文部省入省

1996年 4 月 オーストラリア雇用·教育. 訓練省

1997年 8 月 福岡県警察本部生活安全部 少年課長

1999年10月 大臣官房総務課秘書官事務 取扱

2001年 1 月 大臣官房総務課補佐（兼）内 閣参事官補佐（内閣副長官補 付) 特殊法人等改革推進室

2002年 4 月 三重県教育委員会学校教育 分野総括マネージャー

2006年 7 月 大臣官房企画官（兼）官房 総務課行政改革推進室長等

2007年 4 月＼cjkstart初等中等教育局企画官 2008年 7 月 高等教育局専門教育課長 (現職) 